\title{
STUDI AKURASI PENGUKURAN GNSS JARING MAKRO TAHUN 2016 DAN 2017 PADA PEMANTAUAN BENDUNGAN SERMO
}

\author{
Muhammad Iqbal Taftazani' ${ }^{1}$, Yulaikhah ${ }^{2}$ \\ ${ }^{1}$ Departemen Teknologi Kebumian/Sekolah Vokasi, Universitas Gadjah Mada, Indonesia \\ Email: ${ }^{1}$ iqbaltaftazani@ugm.ac.id \\ ${ }^{2}$ Departemen Teknik Geodesi/Fakultas Teknik, Universitas Gadjah Mada, Indonesia \\ Email: ${ }^{2}$ yulaikhah@ugm.ac.id
}

\begin{abstract}
Monitoring of deformation on Sermo Dam has been widely practiced. One of them is by installing the monitoring point, located inside the Sermo Dam area called the micro network, and outside the dam called macro network. The installation of the micro network monitoring point aims to monitor the deformation of the dam due to the volume of water. The macro network monitoring point aims to monitor the effect of the existence of an active fault under the dam. In the last few years, monitoring in Sermo Dam has been done using GNSS technology. This paper intends to present the results of the accuracy represented by the deviation standard value of the measurement point at the macro net on the GNSS observation in 2016 and 2017. The objective is to compare the accuracy resulting from various GNSS processing strategies in observation 2016 and 2017, evaluation of GNSS measurements that can be used as guidance in subsequent GNSS measurements. The result shows that GNSS measurement in 2017 using two IGS reference points (BAKO and COCO) has a better standard deviation value compared to the 2016 measurement by the difference 1-5 mm on the Xaxis, 1-9 mm on the Y axis, and 1-2 mm on the Z axis. In the GNSS data processing using seven IGS reference points (BAKO, COCO, KARR, DARW, GUUG, PIMO, SHAO) in 2016 mostly has a better standard deviation compared to 2017 measurement except in MAK5 with the difference 0-4 mm on the Xaxis, 1-10 mm on Y axis, and 0-2 $\mathrm{mm}$ on $Z$ axis. As for the value of coordinate data processing in 2016 and 2017 on the two processing strategies there are differences in coordinate values that indicate the movement of monitoring points of macro network. However, the vector of the point movement that occurs in the two strategies has a different direction. This requires verification in-depth research and focused on the deformation of the Sermo Dam monitoring point.
\end{abstract}

Keywords: macro, standard deviation, GNSS, IGS, point movement.

\section{PENDAHULUAN}

\subsection{Latar Belakang}

Bendungan Sermo terletak sekitar $20 \mathrm{~km}$ ke arah barat dari pusat kota Yogyakarta. Pada awal pembangunannya Bendungan Sermo difungsikan untuk tampungan air yang selanjutnya digunakan untuk irigasi pertanian di sekitarnya. Pada perkembangannya, Bendungan Sermo telah bertambah fungsinya selain sebagai irigasi, yaitu sebagai sarana olahraga dan sarana wisata.

Bendungan Sermo selain memiliki pesona keindahan, ternyata juga memiliki potensi bahaya karena fungsi dan keberadaannya. Sebagai penampungan air, Bendungan Sermo mendapatkan suplai air dari beberapa sungai di sekitarnya. Selain membawa air, sungai di sekitar Bendungan Sermo terkadang juga membawa material endapan yang lama-kelamaan dapat menyebabkan pendangkalan Bendungan Sermo. Selain itu keberadaan Bendungan Sermo juga memiliki potensi bahaya lain yaitu denga keberadaan sesar di bawah Bendungan Sermo. Keberadaan sesar tersebut disajikan dalam Gambar 1 berikut.
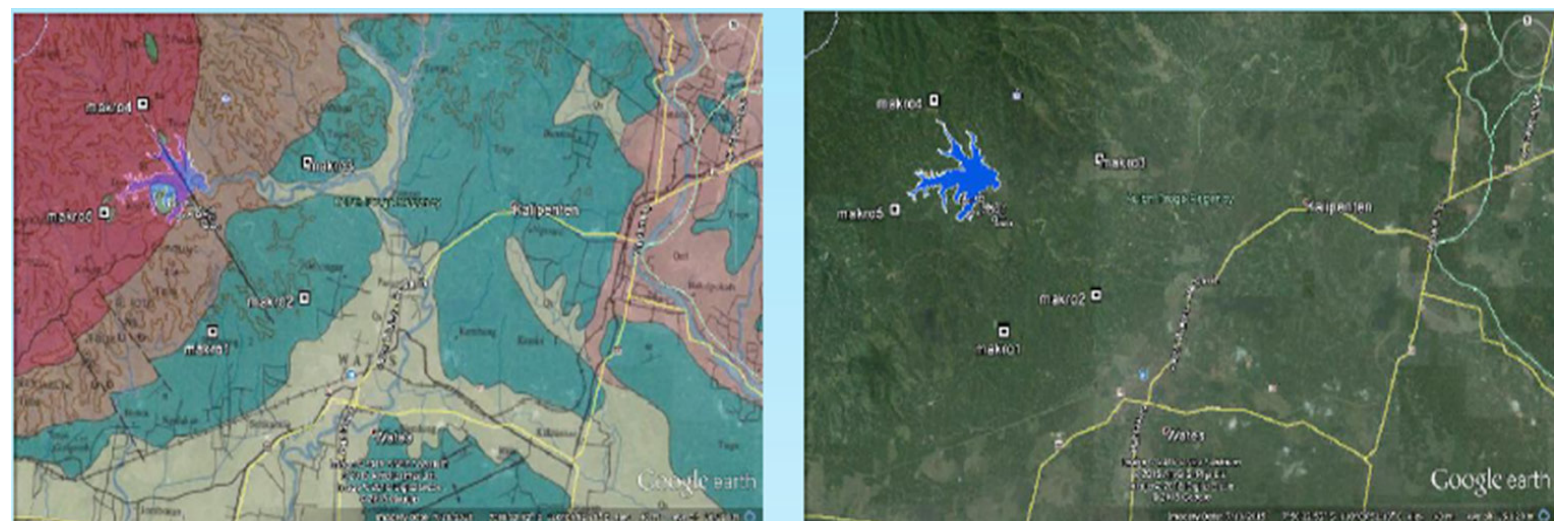

Gambar 1. Lokasi keberadaan sesar di bawah Bendungan Sermo

(GoogleEarth, 2015; Rahardjo, dkk., 1995) 
Gambar 1 di atas merupakan penggabungan dari peta geologi lembar Yogyakarta tahun 1995 dan citra satelit dari GoogleEarth. Keberadaan sesar ditandai dengan adanya garis hitam yang memanjang tepat di bawah Bendungan Sermo.

Untuk melakukan pemantauan dampak keberadaan sesar pada Bendungan Sermo diperlukan titik-titik pemantauan yang oleh Waljiyanto, dkk. (2015) dalam penelitiannya telah memasang sejumlah titik pemantauan Bendungan Sermo, baik di dalam area bendungan dan di luar area bendungan. Adapun dalam penentuan koordinat dan pergerakan titik pemantauan Bendungan Sermo dapat menerapkan cabang ilmu geodesi-geomatika. Beberapa metode yang dapat digunakan dalam hal tersebut adalah Metode Radargrametri dan Metode Pengamatan GNSS (Massonnet, 1998) dimana dalam penelitian ini menggunakan Metode Pengamatan GNSS yang dapat menghasilkan nilai koordinat yang lebih akurat yaitu hingga fraksi cm atau mm (Abidin, 2007).

\subsection{Tujuan Penelitian}

Penelitian ini adalah salah satu pengembangan dari penelitian yang dilakukan oleh Waljiyanto, dkk. (2015), dimana pada hasil penelitian tersebut telah terpasang jaring pemantauan di Bendungan Sermo yang terbagi dalam dua jaring pengamatan. Pertama, jaring pengamatan mikro yang berfungsi untuk meneliti deformasi di area bendungan. Kedua, jaring pengamatan makro yang bertujuan untuk meneliti deformasi akibat keberadaan sesar di bawah Bendungan Sermo. Penelitian ini secara khusus membahas tentang studi akurasi dari pengukuran GNSS yang telah dilakukan pada tahun 2016 dan 2017 pada jaring makro. Maksud dari penelitian ini adalah untuk melihat sejauh mana akurasi yang didapatkan pada pengukuran tahun 2016 dan 2017, dalam hal ini adalah nilai simpangan baku yang dihasilkan dari pengolahan data GNSS dengan strategi yang beragam serta untuk menganalisis apakah ada perbedaan yang signifikan dari nilai akurasi yang dihasilkan beserta penyebab perbedaan akurasi yang dihasilkan. Selain itu, penelitian ini juga bermaksud untuk mendeteksi ada tidaknya pergerakan titik pada jaring makro pemantauan Bendungan Sermo. Deteksi pergerakan titik ini dihasilkan dari analisis data koordinat yang dihasilkan pada epok pengamatan tahun 2016 dan 2017.

\subsection{Pembatasan Masalah}

Untuk mencapai tujuan di atas, perlu ditetapkan beberapa batasan masalah, antara lain:

1. Penelitian ini merupakan bagian kecil dari penelitian menyeluruh tentang deformasi Bendungan Sermo yang meninjau secara spesifik pada aspek pengukuran GNSS dan nilai akurasinya pada titik kontrol jaring makro;

2. Pada aspek pergerakan titik pemantauan jaring makro, dalam penelitian ini ditinjau dari perbedaan nilai koordinat yang dihasilkan dari pengolahan data GNSS tahun 2016 dan 2017 yang menghasilkan nilai simpangan baku terkecil. Sedangkan untuk mendapatkan nilai pergerakan titik pemantuan secara lebih detail dan akurat, diperlukan penelitian mengenai studi deformasi yang lebih mendalam.

\subsection{Tinjauan Pustaka}

Waljiyanto, dkk. (2015) meneliti pengaruh keberadaan sesar di Bendungan Sermo dengan memasang titik pemantauan pada jaring di dalam area dan di luar area bendungan. Hasilnya adalah telah terpasangnya sejumlah titik pemantauan pada jaring mikro (di dalam area bendungan) dan jaring makro (di luar bendungan) yang secara khusus digunakan untuk memantau pengaruh keberadaan sesar di Bendungan Sermo.

Yulaikhah, dkk. (2017) meneliti deformasi titik kontrol pemantauan Bendungan Sermo pada tahun 2015-2016 di semua jaring dengan menggunakan perangkat lunak GAMIT/GLOBK. Hasilnya adalah terjadi deformasi pada titik-titik kontrol pemantauan yang ditandai dengan perbedaan nilai koordinat yang bervariasi yaitu sebesar $0,12-1,68 \mathrm{~cm}$ pada komponen N; 0,21-0,65 cm pada komponen E; dan 2,71-16,34 cm pada komponen U (vertikal).

Ningsih (2014) melakukan pemetaan bidang tanah dengan Metode DGPS Post Processing menggunakan Trimble GEOXT 3000 series, hasilnya didapatkan akurasi antara 0,507-0,586 m dan optimal digunakan pada ruang terbuka. Sedangkan jika menggunakan metode absolut, dihasilkan akurasi antara 1,463-2,910 m.

Ardiyanto dan Ramadhan (2010) dalam penelitian melakukan pengukuran titik kontrol horisontal Kawasan Keselamatan Operasi Penerbangan (KKOP) di Poso menggunakan receiver GPS Geodetik L1 Magellan Promark3. Metode pengukurannya dengan metode relatif statik dengan durasi pengukuran selama 60 menit, dihasilkan bahwa ketelitian baseline yang dihasilkan memiliki nilai dibawah $1 \mathrm{~cm}$. Hal ini terjadi karena pengukuran dilakukan pada area terbuka dan minim obstruksi sehingga tidak terpengaruh oleh efek multipath.

Taftazani (2013) menuliskan bahwa penentuan posisi dengan GPS dapat dilakukan dengan menggunakan metode relatif atau diferensial yang menggunakan dua atau lebih receiver GPS. Penentuan posisi relatif adalah penentuan vektor jarak antara dua stasiun pengamatan, yang dikenal sebagai jarak basis (baseline). Penentuan posisi relatif melibatkan pengamatan 
secara simultan dari beberapa satelit dengan menggunakan minimal dua receiver GPS. Data ukuran pengamatan yang digunakan dalam penentuan posisi secara relatif dapat berupa pseudorange maupun carrier beat phase. Pada penentuan posisi teliti cenderung digunakan carrier beat phase (Leick, 2004). Penentuan posisi secara diferensial dapat memberikan ketelitian posisi yang relatif tinggi dengan level $\mathrm{cm}$ sampai dengan mm. Teknik yang digunakan pada penentuan posisi secara diferensial adalah teknik differencing, yakni dengan mengurangkan data pengamatan GPS untuk mengeliminasi dan mereduksi efek dari sebagian kesalahan dan bias yang terjadi pada saat melakukan pengamatan GPS sehingga data pengamatan hasil pengurangan tersebut menjadi relatif lebih teliti. Dalam pengolahan data pengamatan GPS dikenal beberapa teknik differencing, yaitu single differencing, double differencing, dan triple differencing.

Dari beberapa pustaka di atas bahwa dalam pengukuran titik kontrol pemantauan yang berfungsi juga sebagai titik pemantauan deformasi, khususnya pada Bendungan Sermo dapat diukur menggunakan teknologi GNSS. Adapun metode terbaik yang digunakan adalah dengan metode relatif statik.

\section{BAHAN DAN METODE PENELITIAN}

\subsection{Alat dan Bahan}

Alat dan bahan yang digunakan dalam penelitian ini terbagi dalam dua kategori, yaitu perangkat keras dan perangkat lunak. Perangkat keras yang digunakan adalah sebagai berikut:

1. Seperangakat receiver GNSS Geodetik double frekuensi untuk akuisisi data;

2. Seperangkat komputer dengan sistem operasi Linux 16.04 LTS untuk pengolahan data GNSS;

3. Seperangkat komputer dengan sistem operasi Windows 10 Profesional untuk pengolahan awal dan untuk penulisan makalah, adapun perangkat lunak yang digunakan adalah sebagai berikut:

a. TEQC untuk mengonversi data mentah hasil pengukuran menjadi data RINEX serta untuk melakukan pengecekan kualitas awal data GNSS;

b. GAMIT 10.61 untuk pengolahan data GNSS menjadi data koordinat kartesi global;

c. Microsoft Office (Excel dan Word) untuk analisis data hasil koordinat dan untuk penulisan makalah.

d. Bahan yang digunakan dalam penelitian ini terdiri data primer, data sekunder, dan data pendukung lainnya, antara lain:

4. Data primer, berupa data mentah hasil pengukuran GNSS tahun 2016 dan 2017 (format *.jps dan *.t00) yang selanjutnya dikonversi menjadi RINEX menggunakan perangkat lunak TEQC;

5. Data sekunder, berupa data GNSS titik referensi IGS yang diunduh dari ftp://garner.ucsd.edu;

6. Data pendukung lainnya, antara lain:

a. Data broadcast ephemeris sebagai pelengkap data untuk pengolahan data GNSS menggunakan GAMIT;

b. Data gelombang laut (otl_FES2004.grid);

c. Data pemodelan cuaca (vmflgrid.2011);

d. Data atmosfer (atmdisp_cd.2011).

\subsection{Metode Pengamatan dan Pengolahan GNSS}

Pengamatan GNSS dalam penelitian ini dilakukan dengan metode relatif statik, dimana dibutuhkan minimal dua receiver GNSS, satu sebagai base dan lainnya sebagai rover (berdiri di titik yang akan diukur koordinatnya). Dalam kasus ini, rover didirikan di atas titik kontrol pemantauan jaring makro di Bendungan Sermo, sedangkan base yang digunakan adalah titik referensi IGS global. Pemilihan base juga dapat dilakukan pada saat proses pengolahan, karena data titik referensi IGS dapat diunduh dari laman penyedia data IGS di alamat ftp://garner.ucsd.edu. Pengamatan GNSS dibuat untuk memenuhi spesifikasi pengukuran orde 0 , yang secara umum durasi pengukurannya minimal selama 24 jam, menggunakan GPS/GNSS tipe double frekuensi dengan interval perekaman data setiap 30 detik. Secara lebih detail spesifikasi pengukuran disajikan dalam Tabel 1. 
Tabel 1. Spesifikasi teknis pengukuran JKH

\begin{tabular}{|c|c|c|c|c|c|c|}
\hline & \multicolumn{6}{|c|}{ Orde jaringan } \\
\hline & 00 & $\mathbf{0}$ & 1 & 2 & 3 & 4 (GPS) \\
\hline Metode pengamatan & $\begin{array}{c}\text { GPS } \\
\text { kontinu }\end{array}$ & survei GPS & survei GPS & survei GPS & survei GPS & survei GPS \\
\hline Lama pengamatan per sesi (minimum) & kontinu & 24 jam & 6 jam & 2 jam & 1 jam & $0.25 \mathrm{jam}$ \\
\hline $\begin{array}{l}\text { Data pengamatan utama untuk } \\
\text { penentuan posisi }\end{array}$ & $\begin{array}{l}\text { fase dua } \\
\text { frekuensi }\end{array}$ & $\begin{array}{l}\text { fase dua } \\
\text { frekuensi }\end{array}$ & $\begin{array}{l}\text { fase dua } \\
\text { frekuensi }\end{array}$ & $\begin{array}{l}\text { fase dua } \\
\text { frekuensi }\end{array}$ & $\begin{array}{l}\text { fase satu } \\
\text { frekuensi }\end{array}$ & $\begin{array}{l}\text { fase satu } \\
\text { frekuensi }\end{array}$ \\
\hline Moda pengamatan & jaring tetap & jaring & jaring & jaring & jaring & radial \\
\hline \multicolumn{7}{|l|}{ Pengamatan independen di setiap titik } \\
\hline $\begin{array}{l}\text { - setidaknya } 3 \text { kali (\% dari jumlah } \\
\text { titik) }\end{array}$ & $100 \%$ & $50 \%$ & $40 \%$ & $20 \%$ & $10 \%$ & - \\
\hline $\begin{array}{l}\text { - setidaknya } 2 \text { kali (\% dari jumlah } \\
\text { titik) }\end{array}$ & $100 \%$ & $100 \%$ & $100 \%$ & $100 \%$ & $100 \%$ & - \\
\hline Interval data pengamatan (detik) & 30 & 30 & 30 & 15 & 15 & 15 \\
\hline Jumlah satelit minimum & tidak ada & 4 satelit & & & & \\
\hline Nilai PDOP yang diperlukan & tidak ada & $\begin{array}{l}\text { lebih kecil } \\
\text { dari } 10\end{array}$ & & & & \\
\hline Elevasi satelit minimum & $15^{\circ}$ & & & & & \\
\hline Pengamatan data meteorologis & ya & ya & ya & tidak & tidak & tidak \\
\hline
\end{tabular}

Sumber: BSN, SNI JKH, 2002

Tabel 1 di atas menyajikan spesifikasi Teknis Standar Pengukuran Jaring Kontrol Horizontal. Dalam penelitian ini pengamatan GNSS dilakukan selama 4 hari (3-4 DOY) terus menerus (4 DOY) dengan interval perekaman data setiap 15 detik. Adapun dalam spesifikasi teknis di Tabel 1, pada orde 0 tertuliskan lama pengamatan minimal 24 jam dan interval pengamatan selama 30 detik. Sedangkan dalam penelitian ini pengukuran dilaksanakan selama 4 hari berturut-turut dan dengan interval pengamatan selama 15 detik, lebih rapat dibandingkan dengan spesifikasi standar sehingga dapat dikatakan bahwa pengukuran dalam penelitian ini telah memenuhi ketentuan standar spesifikasi orde 0. Gambar proses pengamatan GNSS dapat dilihat pada Gambar 2.
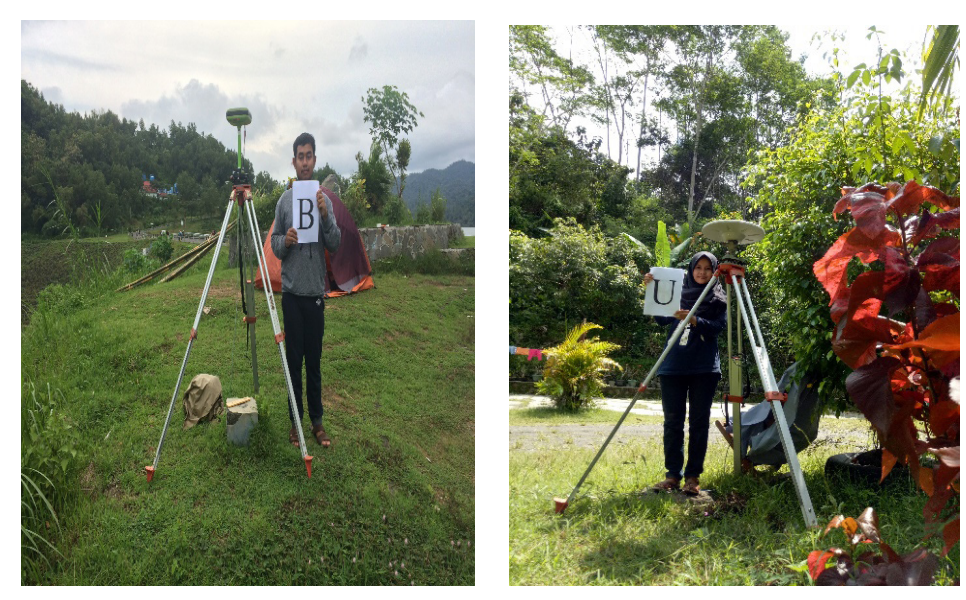

Gambar 2. Proses pengamatan GNSS

Setelah dilakukan pengamatan, luaran dari receiver GNSS adalah data mentah dengan format *.jps (format data dari receiver merk Javad) atau *.t00 (format data dari receiver merk Trimble). Sebelum dapat diolah menggunakan perangkat lunak GAMIT/GLOBK versi 10.61, data GNSS hasil pengukuran terlebih dahulu dikonversi dari data mentah menjadi data RINEX (berformat *.16o atau *.17o) menggunakan TEQC. Kemudian dilakukan pengecekan kualitas data juga menggunakan TEQC. Kualitas data yang dicek meliputi efek multipath dan delay ionosfer. 
Proses selanjutnya adalah pengolahan data GNSS menggunakan perangkat lunak GAMIT/GLOBK versi 10.61 . Pengolahan data GNSS menggunakan perangkat lunak GAMIT/GLOBK memerlukan data rinex tambahan dari titik referensi IGS. Titik referensi IGS yang digunakan sesuai strategi yang dilakukan dalam pengolahannya dimana pada penelitian ini dilakukan dengan dua strategi. Strategi pertama yaitu pengolahan dengan menggunakan dua titik referensi IGS, dengan mempertimbangkan aspek keterbentukan jaring pengolahan yang berbentuk segitiga. Titik referensi IGS yang digunakan adalah BAKO dan COCO. Strategi kedua yaitu dengan menggunakan tujuh titik referensi IGS, yaitu BAKO, COCO, DARW, KARR, PIMO, GUUG, dan SHAO. Strategi ini dilakukan dengan pertimbangan dari penelitian yang dilakukan oleh Leonard (2009) yang menyatakan bahwa ketelitian posisi meningkat dalam fraksi 1/10 mm pada saat menggunakan tujuh titik referensi dibandingkan jika menggunakan empat titik referensi. Setelah itu, meningkat hanya pada fraksi $1 / 100 \mathrm{~mm}$ saat jumlah titik referensi menjadi bertambah hingga sembilan sehingga jumlah titik referensi yang berjumlah tujuh merupakan titik referensi yang optimal untuk mendapatkan nilai akurasi yang baik. Pemilihan titik IGS pada kedua strategi tersebut didasarkan pada aspek kedekatan lokasi titik IGS dengan lokasi pengukuran serta aspek ketersediaan data IGS di website penyedia data IGS. Gambar konfigurasi jaring pengolahan pada kedua strategi dapat dilihat pada Gambar 3 di bawah.

Hasil dari pengolahan data GNSS adalah koordinat titik jaring makro untuk tahun pengamatan tahun 2016 dan 2017 yang disajikan menggunakan sistem koordinat kartesian 3D geosentris. Sistem koordinat kartesi 3D memiliki aturan, yaitu titik pusat sistem koordinat kartesian terletak pada pusat bumi, sumbu $\mathrm{Z}$ adalah garis dalam arah Conventional Terrestrial Pole (CTP), sumbu X adalah arah perpotongan meredian Greenwich atau meredian nol Conventional Zero Meridian (CZM) yang ditetapkan oleh Burau International de l'Heure (BIH) dan bidang ekuator, sumbu $\mathrm{Y}$ adalah garis pada bidang ekuator yang tegak lurus pada sumbu X dan Z dengan mengikuti kaidah tangan kanan di mana dalam penelitian ini sumbu Y mewakili komponen vertikal (Leick, dkk., 2015).

Pada dua epok pengamatan tersebut juga dilakukan pengecekan ada tidaknya pergeseran titik pada pada jaring makro pengamatan Bendungan Sermo dengan menyelisihkan nilai koordinat pada setiap epok pengamatan.

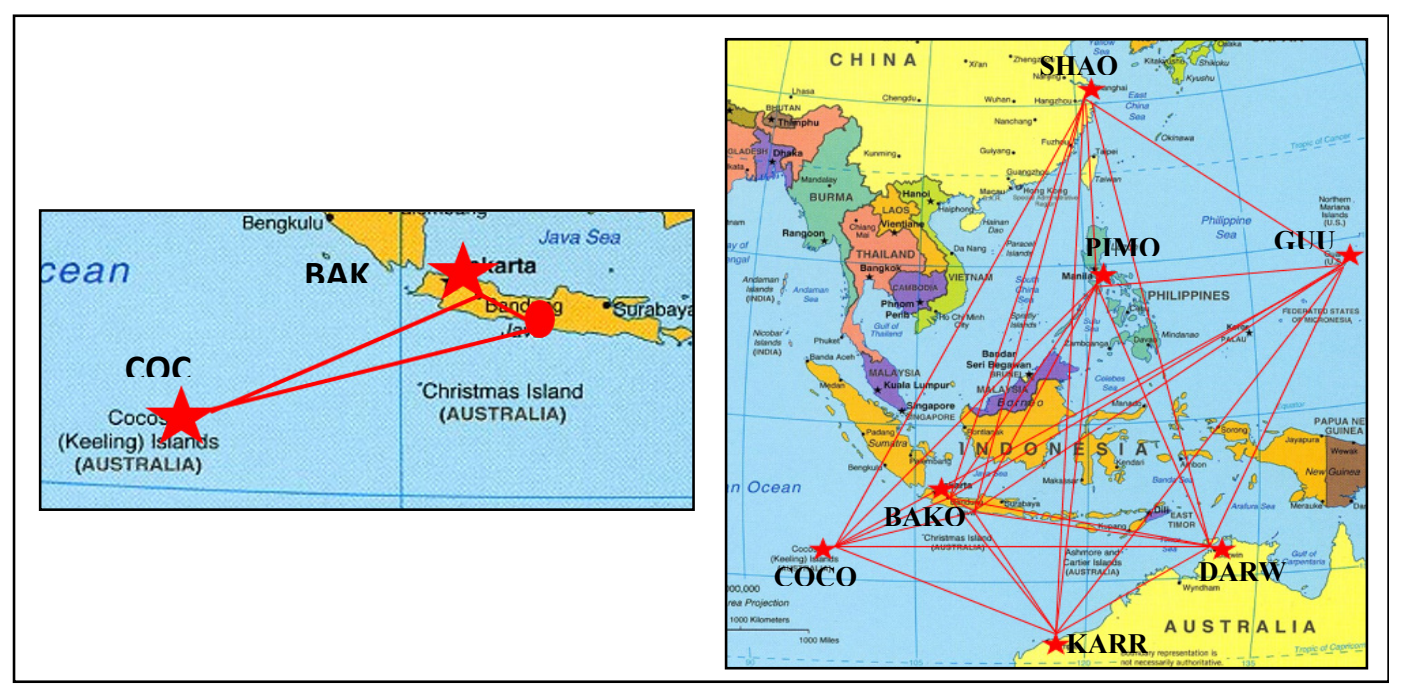

Gambar 3. Desain konfigurasi jaring pengolahan strategi pertama (kiri) dan strategi kedua (kanan)

\subsection{Hasil dan pembahasan}

Hasil dari penelitian ini terdiri dari beberapa hal, pertama adalah hasil pengecekan kualitas, kedua hasil pengolahan data GNSS yang berupa nilai koordinat dan simpangan bakunya pada dua epok pengamatan, dan ketiga adalah nilai pergerakan titik kontrol jaring makro pada pengamatan Bendungan Sermo. Hasil pengecekan kualitas data GNSS disajikan pada Tabel 2 dan 3 berikut. 
Tabel 2. Hasil pengecekan kualitas data pengamatan GNSS tahun 2016

\begin{tabular}{|c|c|c|c|c|c|c|}
\hline \multirow{2}{*}{ Nama titik } & \multirow{2}{*}{$\begin{array}{c}\text { Durasi pengamatan } \\
\text { (hari) }\end{array}$} & \multicolumn{2}{|c|}{ MP (m) } & \multicolumn{2}{|r|}{ IOD } & \multirow{2}{*}{$\%$ Rasio } \\
\hline & & MP1 & MP2 & IOD slips & IOD or MP slips & \\
\hline MAK1 & 3,02 & 1,56 & 1,56 & 509 & 685 & 81 \\
\hline MAK2 & 3,03 & 1,57 & 1,44 & 584 & 840 & 84 \\
\hline MAK3 & 3,03 & 0,89 & 0,95 & 236 & 343 & 91 \\
\hline MAK4 & 3,01 & 1,52 & 1,58 & 454 & 651 & 74 \\
\hline MAK5 & 3,03 & 0,66 & 0,78 & 84 & 150 & 26 \\
\hline
\end{tabular}

Tabel 3. Hasil pengecekan kualitas data pengamatan GNSS tahun 2017

\begin{tabular}{|c|c|c|c|c|c|c|}
\hline \multirow[b]{2}{*}{$\begin{array}{l}\text { Nama } \\
\text { titik }\end{array}$} & \multirow{2}{*}{$\begin{array}{c}\text { Durasi } \\
\text { pengamatan } \\
\text { (hari) }\end{array}$} & \multicolumn{2}{|c|}{ MP (m) } & \multicolumn{2}{|c|}{ IOD } & \multirow{2}{*}{$\begin{array}{c}\% \\
\text { Rasio }\end{array}$} \\
\hline & & MP1 & MP2 & IOD slips & $\begin{array}{l}\text { IOD or MP } \\
\text { slips }\end{array}$ & \\
\hline MAK1 & 1,83 & 1,44 & 1,63 & 23 & 83 & 81 \\
\hline MAK2 & 3,29 & 1,60 & 1,61 & 20 & 77 & 82 \\
\hline MAK3 & 3,30 & 0,91 & 0,98 & 10 & 12 & 89 \\
\hline MAK4 & 3,26 & 1,67 & 1,58 & 17 & 46 & 68 \\
\hline MAK5 & 3,22 & 0,69 & 0,74 & 2780 & 2576 & 62 \\
\hline
\end{tabular}

Tabel 2 dan 3 di atas menyajikan hasil pengecekan kualitas data rinex pemantauan GNSS taun 2016 dan 2017. Pengecekan kualitas meliputi durasi pengamatan, multipath (MP1 dan MP2), delay ionosfer (IOD) serta \% rasio yang menunjukkan prosentase data terekam dibandingkan jumlah kemungkinan data diperoleh. Hasilnya diperoleh secara umum nilai multipath pada pengamatan tahun 2016 lebih baik dibandingkan dengan tahun 2017, sedangkan nilai delay ionosfer pada tahun 2017 lebih baik dibandingkan dengan tahun 2016. Pada aspek \% rasio data memiliki nilai yang hampir sama, kecuali pada titik MAK5 pada tahun 2016 yang memiliki rasio 26\%. Menurut Lestari (2006) dalam Taftazani (2013) menyebutkan bahwa hasil cek data pengamatan memenuhi kriteria apabila:

1. Tidak terjadi ionospheric delay pada rekaman data satelit di elevation mask yang banyak;

2. Efek multipath, MP1 dan MP2 kurang dari 0,5 m;

3. Ionosphere Delay Observable (IOD) dan IOD+MP slips kurang dari 100;

4. Data yang dibuang dari data keseluruhan jumlahnya relatif kecil.

Dari beberapa kriteria di atas, dapat dilihat bahwa data pengamatan tahun 2017 lebih memenuhi kriteria dibandingkan data tahun 2016, hal ini dilihat dari nilai IOD yang kurang dari 100 kecuali pada titik MAK5. Muslim (2011) menyatakan bahwa pengaruh kondisi ionosfer khususnya pada saat badai matahari dapat menurunkan akurasi pengamatan GNSS sampai 60\%. Namun demikian, nilai MP pada pengamatan 2016 secara umum lebih baik daripada tahun 2017 kecuali pada titik MAK1, namun pada durasi pengamatan pada tahun 2017 titik MAK1 memiliki durasi yang paling singkat dibanding pengamatan lainnya. Pada aspek \% rasio pada pengamatan tahun 2017 secara umum rata-ratanya lebih baik daripada tahun 2016 dan terutama di titik MAK5 dimana pada tahun $2016 \%$ rasionya $26 \%$.

Pengolahan data GNSS, seperti diuraikan di atas menggunakan dua strategi, pada strategi pertama pengolahan data GNSS dengan menggunakan dua titik referensi IGS disajikan pada Tabel 4 berikut. Sedangkan hasil pengolahan pada strategi kedua dengan menggunakan tujuh titik referensi IGS disajikan pada Tabel 5.

Tabel 4 dan 5 menyajikan koordinat dan simpangan baku hasil pengolahan data GNSS jaring makro pada titik pemantauan Bendungan Sermo dengan menggunakan dua strategi pengolahan. Secara umum, nilai simpangan baku pada sumbu-Y hasil pengolahan pada kedua strategi memiliki nilai yang lebih besar dibandingkan sumbu X dan Z. Hal ini disebabkan karena sumbu Y merupakan komponen vertikal dan secara geometri satelit GNSS tidak memungkinkan pengamatan di bawah horison sehingga kekuatan ikatan jaringan komponen vertikal lebih lemah dibandingkan horizontal (Taftazani, 2013).

Pada pengolahan strategi pertama, hasil simpangan baku tahun 2017 memiliki nilai yang lebih baik daripada tahun 2016, akan tetapi pada strategi kedua hasilnya berkebalikan dimana nilai simpangan baku 2016 memiliki nilai yang lebih baik daripada tahun 2017. 
Tabel 4. Hasil pengolahan data GNSS dengan dua titik referensi IGS

\begin{tabular}{|c|c|c|c|c|c|c|}
\hline \multirow{2}{*}{ Titik } & \multirow{2}{*}{ Sumbu } & \multicolumn{2}{|l|}{2016} & \multicolumn{2}{|c|}{2017} & \multirow{2}{*}{$\begin{array}{c}\text { Selisih S. } \\
\text { baku }\end{array}$} \\
\hline & & Koordinat & S. baku & Koordinat & S. baku & \\
\hline \multirow{3}{*}{ MAK1_GPS } & $\mathrm{X}$ & $-2173894,945$ & 0,022 & $-2173894,998$ & 0,021 & $-0,001$ \\
\hline & $\mathrm{Y}$ & 5933154,596 & 0,043 & 5933154,655 & 0,042 & $-0,001$ \\
\hline & $\mathrm{Z}$ & $-865359,061$ & 0,013 & $-865359,090$ & 0,012 & $-0,001$ \\
\hline \multirow{3}{*}{ MAK2_GPS } & $\mathrm{X}$ & $-2177261,511$ & 0,021 & $-2177261,525$ & 0,018 & $-0,003$ \\
\hline & $\mathrm{Y}$ & 5932017,245 & 0,041 & 5932017,263 & 0,037 & $-0,004$ \\
\hline & $\mathrm{Z}$ & $-864474,086$ & 0,012 & $-864474,095$ & 0,010 & $-0,002$ \\
\hline \multirow{3}{*}{ MAK3_GPS } & $\mathrm{X}$ & $-2177051,089$ & 0,021 & $-2177051,136$ & 0,017 & $-0,003$ \\
\hline & $\mathrm{Y}$ & 5932473,443 & 0,040 & 5932473,466 & 0,035 & $-0,005$ \\
\hline & $\mathrm{Z}$ & $-861869,842$ & 0,012 & $-861869,864$ & 0,010 & $-0,002$ \\
\hline \multirow{3}{*}{ MAK4_GPS } & $\mathrm{X}$ & $-2172643,063$ & 0,021 & $-2172643,088$ & 0,018 & $-0,002$ \\
\hline & $\mathrm{Y}$ & 5934345,825 & 0,041 & 5934345,853 & 0,038 & $-0,003$ \\
\hline & Z & $-860932,125$ & 0,012 & $-860932,144$ & 0,011 & $-0,001$ \\
\hline \multirow{3}{*}{ MAK5_GPS } & $\mathrm{X}$ & $-2171606,479$ & 0,023 & $-2171606,512$ & 0,019 & $-0,005$ \\
\hline & $\mathrm{Y}$ & 5934545,130 & 0,049 & 5934545,192 & 0,040 & $-0,009$ \\
\hline & Z & $-862382,537$ & 0,013 & $-862382,572$ & 0,011 & $-0,002$ \\
\hline
\end{tabular}

Tabel 5. Hasil pengolahan data GNSS dengan tujuh titik referensi IGS

\begin{tabular}{|c|c|c|c|c|c|c|}
\hline \multirow{2}{*}{ Titik } & \multirow{2}{*}{ Sumbu } & \multicolumn{2}{|l|}{2016} & \multicolumn{2}{|c|}{2017} & \multirow{2}{*}{$\begin{array}{c}\text { Selisih } \\
\text { S. } \\
\text { baku }\end{array}$} \\
\hline & & Koordinat & S. baku & Koordinat & S. baku & \\
\hline \multirow{3}{*}{$\begin{array}{c}\text { MAK1 } \\
\text { GPS }\end{array}$} & $\mathrm{X}$ & $-2173894,945$ & 0,008 & $-2173894,998$ & 0,012 & 0,003 \\
\hline & Y & 5933154,596 & 0,016 & 5933154,655 & 0,021 & 0,006 \\
\hline & Z & $-865359,061$ & 0,005 & $-865359,090$ & 0,007 & 0,002 \\
\hline \multirow{3}{*}{$\begin{array}{c}\text { MAK2 } \\
\text { GPS }\end{array}$} & $X$ & $-2177261,511$ & 0,005 & $-2177261,525$ & 0,007 & 0,001 \\
\hline & Y & 5932017,245 & 0,011 & 5932017,263 & 0,015 & 0,005 \\
\hline & Z & $-864474,086$ & 0,003 & $-864474,095$ & 0,003 & 0,001 \\
\hline \multirow{3}{*}{$\begin{array}{c}\text { MAK3 } \\
\text { GPS }\end{array}$} & $X$ & $-2177051,089$ & 0,005 & $-2177051,136$ & 0,005 & 0,000 \\
\hline & Y & 5932473,443 & 0,010 & 5932473,466 & 0,011 & 0,001 \\
\hline & Z & $-861869,842$ & 0,002 & $-861869,864$ & 0,002 & 0,000 \\
\hline \multirow{3}{*}{$\begin{array}{c}\text { MAK4 } \\
\text { GPS }\end{array}$} & $X$ & $-2172643,063$ & 0,006 & $-2172643,088$ & 0,008 & 0,002 \\
\hline & Y & 5934345,825 & 0,012 & 5934345,853 & 0,016 & 0,004 \\
\hline & Z & $-860932,125$ & 0,004 & $-860932,144$ & 0,005 & 0,001 \\
\hline \multirow{3}{*}{$\begin{array}{c}\text { MAK5 } \\
\text { GPS }\end{array}$} & $X$ & $-2171606,479$ & 0,013 & $-2171606,512$ & 0,008 & $-0,004$ \\
\hline & $Y$ & 5934545,130 & 0,030 & 5934545,192 & 0,020 & $-0,010$ \\
\hline & Z & $-862382,537$ & 0,007 & $-862382,572$ & 0,005 & $-0,002$ \\
\hline
\end{tabular}

Jika hasil pengolahan strategi pertama dikaitkan dengan hasil pengecekan kualitas data, didapatkan bahwa pada tahun 2017 memiliki nilai MP yang relatif besar dibandingkan dengan 2016, sedangkan nilai IOD 2017 lebih kecil dibandingkan tahun 2016. Nilai simpangan baku pada hasil pengolahan didapatkan bahwa pengolahan tahun 2016 memiliki nilai simpangan baku yang lebih besar dibandingkan 2017, yang dapat diartikan pengukuran tahun 2016 memiliki hasil yang lebih akurat daripada tahun 2017. Dari hasil itu dapat diambil kesimpulan sementara bahwa nilai IOD memiliki pengaruh yang cukup signifikan terhadap akurasi hasil pengolahan. Adapun pada strategi kedua, simpangan baku tahun 2017 memiliki nilai yang lebih besar daripada tahun 2016, kecuali pada titik MAK5 yang nilai simpangan baku tahun 2017 lebih kecil dibandingkan tahun 2016. Besarnya nilai simpangna baku tahun 2017 ini salah satunya disebabkan karena nilai MP pada pengamatan GNSS tahun 2017 memiliki nilai yang lebih besar dibandingkan tahun 2016, kecuali pada titik MAK1 yang nilai MP pada pengamatan tahun 2017 lebih kecil daripada tahun 2016. Akan tetapi, durasi pengamatan di titik MAK1 pada tahun 2017 lebih singkat dibandingkan titik-titik lainnya. Pada titik MAK5 pengamatan tahun 2017 memiliki nilai simpangan baku yang lebih kecil dibandingkan dengan tahun 2016, karena \% rasio pengamatan tahun 2016 jauh lebih sedikit (26\%) dibandingkan dengan tahun 2017 (62\%). 
Selain itu perbedaan nilai simpangan baku pada pengolahan dengan strategi pertama dan kedua dapat juga disebabkan karena konfigurasi jaringan titik referensi IGS yang digunakan. Pada strategi pertama hanya menggunakan dua titik referensi IGS, sedangkan pada strategi kedua mengunakan tujuh titik referensi IGS. Perbedaan jumlah titik referensi IGS ini secara signifikan menghasilkan nilai simpangan baku yang lebih kecil pada pengolahan GNSS dengan strategi kedua (tujuh titik IGS) dibandingkan dengan strategi pertama (dua titik IGS). Hal ini sesuai dengan penelitian oleh Leonard (2009), yang menyatakan bahwa semakin banyak jumlah titik referensi IGS hingga tujuh titik referensi IGS yang digunakan dalam pengolahan menggunakan GAMIT akan meningkatkan akurasi pengolahan secara signifikan.

Pada aspek deteksi pergerakan titik, hasil pengolahan yang digunakan untuk analisis deteksi pergerakan adalah yang memiliki nilai simpangan baku terkecil. Dalam hal ini hasil pengolahan pada strategi kedua yang memiliki nilai simpangan baku antara 0-4 mm pada sumbu-X, 1-10 mm pada sumbu-Y, dan 0-2 mm pada sumbu-Z. Deteksi pergerakan dilakukan dengan menyelisihkan nilai koordinat hasil pengolahan tahun 2017 dan 2016 . Hasil selisih koordinat disajikan pada Tabel 6.

Tabel 6 menunjukkan nilai selisih koordinat yang menandakan dimungkinkan adanya pergerakan titik kontrol jaring makro pada pengamatan Bendungan Sermo. Pergerakan titik tersebut berkisar antara 3,1-5,5 cm pada sumbu-X; 1,2-3,3 cm pada sumbu-Y (pergerakan vertikal); dan 0,2-2,8 cm pada sumbu-Z. Tanda negatif (-) pada kolom selisih koordinat menandakan vektor arah pergerakan yang terjadi, sebagai contoh pada titik MAK1 selisih koordinat pada sumbu-X sebesar $-5,5 \mathrm{~cm}$ yang artinya titik kontrol MAK1 mengalami pergerakan sebesar 5,5 cm dengan arah yang berkebalikan dengan sumbu-X. Pada sumbu-Y mengalami pergerakan sebesar 1,2 cm yang searah dengan sumbu-Y. Dan pada sumbu-Z bergerak sebesar 2,2 cm dengan arah yang berkebalikan dengan sumbu-Z. Nilai selisih koordinat yang disajikan pada Tabel 6 harus diuji secara statistik untuk memastikan besar dan vektor arah pergerakan secara lebih akurat.

Tabel 6. Selisih koordinat pengolahan

\begin{tabular}{|c|c|c|c|c|c|c|}
\hline \multirow{2}{*}{ Titik } & \multirow{2}{*}{ Sumbu } & \multicolumn{2}{|c|}{2016} & \multicolumn{2}{|c|}{2017} & \multirow{2}{*}{$\begin{array}{c}\text { Selisih } \\
\text { koordinat }\end{array}$} \\
\hline & & Koordinat & S. baku & Koordinat & S. baku & \\
\hline \multirow{3}{*}{ MAK1_GPS } & $X$ & $-2173894,943$ & 0,008 & $-2173894,998$ & 0,012 & $-0,055$ \\
\hline & $\mathrm{Y}$ & 5933154,636 & 0,016 & 5933154,648 & 0,021 & 0,012 \\
\hline & $\mathrm{Z}$ & $-865359,061$ & 0,005 & $-865359,083$ & 0,007 & $-0,022$ \\
\hline \multirow{3}{*}{ MAK2_GPS } & $\mathrm{X}$ & $-2177261,51$ & 0,005 & $-2177261,533$ & 0,007 & $-0,023$ \\
\hline & $\mathrm{Y}$ & 5932017,284 & 0,011 & 5932017,266 & 0,015 & $-0,018$ \\
\hline & $\mathrm{Z}$ & $-864474,084$ & 0,003 & $-864474,086$ & 0,003 & $-0,002$ \\
\hline \multirow{3}{*}{ MAK3_GPS } & $\mathrm{X}$ & $-2177051,087$ & 0,005 & $-2177051,137$ & 0,005 & $-0,05$ \\
\hline & $\mathrm{Y}$ & 5932473,471 & 0,01 & 5932473,455 & 0,011 & $-0,016$ \\
\hline & Z & $-861869,841$ & 0,002 & $-861869,857$ & 0,002 & $-0,016$ \\
\hline \multirow{3}{*}{ MAK4_GPS } & $\mathrm{X}$ & $-2172643,06$ & 0,006 & $-2172643,091$ & 0,008 & $-0,031$ \\
\hline & $\mathrm{Y}$ & 5934345,857 & 0,012 & 5934345,845 & 0,016 & $-0,012$ \\
\hline & $\mathrm{Z}$ & $-860932,124$ & 0,004 & $-860932,135$ & 0,005 & $-0,011$ \\
\hline \multirow{3}{*}{ MAK5_GPS } & $\mathrm{X}$ & $-2171606,482$ & 0,013 & $-2171606,522$ & 0,008 & $-0,04$ \\
\hline & $\mathrm{Y}$ & 5934545,175 & 0,03 & 5934545,208 & 0,02 & 0,033 \\
\hline & Z & $-862382,54$ & 0,007 & $-862382,568$ & 0,005 & $-0,028$ \\
\hline
\end{tabular}

\section{KESIMPULAN}

Dari pemaparan di atas, kesimpulan yang dapat diambil adalah telah dilakukan pengukuran dan pengolahan data GNSS di lima titik makro pada jaring pengamatan Bendungan Sermo. Pengolahan dilakukan menggunakan perangkat lunak GAMIT dan menggunakan dua strategi pengolahan, yaitu pengolahan dengan dua titik referensi IGS dan pengolahan dengan tujuh titik referensi IGS. Hasil dari pengolahan didapatkan koordinat dan simpangan baku dari titik makro (MAK1, MAK2, MAK3, MAK4, dan MAK5) pada masing-masing tahun pengamatan.

Pada strategi pertama dengan dua titik referensi IGS, didapatkan hasil pengolahan tahun 2017 lebih akurat dibandingkan dengan pengolahan tahun 2016 yang dinyatakan dengan nilai simpangan baku yang lebih kecil. Hal ini disebabkan karena durasi pengamatan harian pada tahun 2017 lebih lama dibandingkan dengan tahun 2017 sehingga data yang diolah pada taun 2017 lebih maksimal dibandingkan dengan data tahun 2016. Sedangkan pada pengolahan data GNSS dengan strategi kedua, didapatkan hasil pengolahan tahun 2016 lebih akurat dibandingkan hasil pengolahan tahun 2017, kecuali pada titik MAK5. Hal ini disebabkan adanya variasi konfigurasi jaringan pengolahan dan variasi jarak baseline 
yang mencolok. Selain itu, dari hasil pengecekan kualitas data dihasilkan nilai multipath (MP) dan delay ionosfer (IOD), keduanya dapat memengaruhi nilai akurasi dari pengolahan yang dihasilkan secara signifikan.

Adapun pada perbandingan nilai akurasi hasil pengolahan pada strategi pertama dan kedua, dihasilkan bahwa nilai akurasi hasil pengolahan strategi kedua lebih baik dibandingkan hasil pengolahan strategi pertama. Hal ini disebabkan karena perbedaan jumlah titik referensi IGS yang digunakan dalam pengolahan. Semakin banyak jumlah titik referensi IGS yang digunakan akan meningkatkan akurasi pengolahan GNSS hingga tujuh titik referensi IGS.

Pada aspek pergerakan titik kontrol, dari hasil pengolahan tahun 2016 dan 2017 terdapat selisih nilai koordinat. Selisih nilai tersebut dimungkinkan adanya pergerakan dalam titik kontrol tersebut. Namun untuk memastikan ada tidaknya pergerakan, berapa pergerakannya dan vektor arah pergerakannya perlu dilakukan uji statistik dan penelitian yang lebih mendalam.

Adapun saran yang dapat diberikan dalam penelitian ini adalah agar penelitian dapat dikembangkan mengenai pengaruh konfigurasi jaringan saat pengolahan data GNSS terhadap hasil akurasi yang dihasilkan. Selain itu juga perlu dilakukan penelitian mendalam tentang pengaruh durasi pengamatan terhadap hasil akurasi pengolahan data GNSS.

\section{UCAPAN TERIMA KASIH}

Ucapan terima kasih disampaikan kepada Sekolah Vokasi Universitas Gadjah Mada yang telah membantu dalam menyediakan dana untuk keperluan penelitian ini. Ucapan terima kasih juga disampaikan kepada Ibu Yulaikhah, Bapak Waljiyanto, Ibu Nurrohmat Widjajanti, Bapak Prijono Nugroho, Bapak Agus Darmawan Adhi, Bapak Bambang Kun Cahyono yang telah membantu membimbing dalam proses perencanaan, pengumpulan data hingga penulisan makalah ini.

\section{DAFTAR PUSTAKA}

Abidin, H.Z. (2007). Penentuan Posisi dengan GPS dan Aplikasinya. (Edisi III). Jakarta: PT. Pradnya Paramitha.

Ardiyanto, R.., and Ramadhan, R.. 2010. Aplikasi GPS Geodetic Dalam Penentuan Titik Kontrol Horisontal Kawasan Keselamatan Operasi Penerbangan (KKOP) Studi Kasus: Bandara Kasiguncu-Poso. Jurnal Sains dan Teknologi Kebumian Indonesia BPPT 1 (3).

Badan Standardisasi Nasional. (2002). Standard Nasional Indonesia Jaring Kontrol Horizontal SNI 19-6724-2002. BSN Indonesia.

Google Earth. (2015). Peta Citra Sermo. Aplikasi Google Earth Akses 22.10.15

Leick, A., Rapoport, L., Tatarnikov, D. (2015). GPS Satellite Surveying. John Wiley \& Sons.

Leonard, Y, R. (2009). Pengaruh Jumlah Titik Ikat pada Proses Perataan Jaring Terhadap Ketelitian Koordinat Titik dalam Jaring GPS Setingkat Orde 0. Skripsi. Jurusan Teknik Geodesi Fakultas Teknik, Universitas Gadjah Mada. Yogyakarta.

Lestari, D. (2006). GPS Study for Resolving the Stability of Borobudur Temple Site. Thesis. School of Surveying and Spatial Information System, Universityof New South Wales. New South Wales.

Massonnet, D., Feigl, K.L. 1998. Radar interferometry and its application to changes in the Earth's surface. Reviews of Geophysics 36 (4), 441-500.

Muslim, Buldan. 2011. Pengarus Ionosfer pada Akurasi Penentuan Posisi Absolut dengan GPS Single Frequency pada Saat Terjadi Badai Matahari. Jurnal Sains Dirgantara 9 (1): 70-89.

Ningsih, A.E. (2014). Kajian Pengukuran dan Pemetaan Bidang Tanah Metode DGPS Post Processing dengan Menggunakan Receiver Trimble Geoxt 3000 Series. Tugas Akhir. Jurusan Teknik Geodesi Fakultas Teknik Universitas Diponegoro. Semarang.

Rahardjo, W., Sukandarrumidi, Rosadi, H.M.D. (1995). Peta Geologi Lembar Yogyakarta. Direktorat Geologi, Departemen Pertambangan Republik Indonesia bekerjasama dengan U.S. Geological Survey.

Sunantyo, T.A., Suryolelono, K. B., Djawahir, F., Swastono, A., Adhi, A.D., Susilo, A. (2012). Design and installation for Dam Monitoring Using Multi sensors: A Case Study at Sermo Dam, Yogyakarta Province, Indonesia. FIG Working Week 2012, Rome, Italy, 6-10 May 2012. 
Taftazani, M.I. (2013). Analisis Geodinamika Lima Stasiun Pasut Pulau Jawa dengan Data Pengamatan GPS Tiga Epok. Tesis. Program Pascasarjana Teknik Geomatika, Fakultas Teknik Universitas Gadjah Mada. Yogyakarta.

Waljiyanto, Widjajanti, N., Yulaikhah, Taftazani, M.I. 2015. Pengembangan Jaring Kontrol Geodesi Pemantau Waduk Sermo. Jurnal Ilmiah Geomatika 21 (2).

Yulaikhah, Widjajanti, N., Nugroho, P., Cahyono, B.K., Waljiyanto, Darmawan, A.A., \& Taftazani, M.I., (2017). The analysis of monitoring control point displacement of Sermo Dam based on the 2015-2016 GNSS Data. AIP Conference Proceedings 1857, 040014. 